\title{
PERSONALITY TRAITS AS PREDICTORS OF AFFECTIVE STYLES AMONG YOUNG PEOPLE
}

ABSTRACT. The focus of this paper is the understanding of personality trait prediction in anticipating a particular affective style among young people. The sample consists of 171 students from University of Priština in Kosovska Mitrovica, of both genders, aged 18-26. The data have been processed using descriptive statistics, correlation and regression analysis, and t-test. The most dominant dimension of personality is agreeableness, and the most dominant dimension of affective styles is adjusting. The prediction of personality dimensions in predicting a certain affective style has been confirmed, so that neuroticism is essential in the prediction of all three affective styles. In the prediction of affective style of concealing, personality traits as a model explain $10.7 \%$ variance, and besides neuroticism $(\beta=-298 ; p<0.01)$, the contribution has been given by extraversion, as well $(\beta=-221, p<0.05)$. The personality traits explain $36.1 \%$ of the variance of adjusting, and the unique contribution has been given by neuroticism $(\beta=-.596, p<0.01)$, while in the prediction of affective style of tolerating, personality traits explain $9.8 \%$ of the total

jelena.davidovic.rakic@pr.ac.rs

miljanapavicevic@yahoo.com

This paper was submitted on August $29^{\text {th }}, 2019$ and accepted for publication at the meeting of the Editorial Board held on September $16^{\text {th }}, 2019$. 
variance, with a significant predictor - neuroticism $(\beta=-.241$, $\mathrm{p}<0.05)$. Gender has not proven to be a significant source of differences in the expression of affective styles, while there are gender differences in the expression of extraversion and agreeableness in favour of female respondents.

KEYWORDS: personality traits; affective style; young people.

INTRODUCTION

Whether the personality model is based on lexical hypothesis or starts from biological bases (Smederevac \& Mitrović, 2018), the inseparable part of personality is made up of emotions. They are an integral part of everyday life, because they are an inseparable factor of social interaction. The significance of emotions for psychological health is emphasized by supporters of opposing psychological points of view: psychoanalytic clinicians and cognitive psychotherapists.

Even Freud pointed out that emotional inhibition is one of the more important causes of mental disorders. More recent views see positive aspects in emotional inhibition as well. Civilisation seems to require that we inhibit spontaneous emotional expression as the correct processes (Gross \& Levenson, 1997). Regardless of whether the emotional reaction is under a minor or greater influence of conscious control, the emotional process serves to create adaptive behaviours (Reeve, 2010). Since the result of emotion regulation is the reduction or reinforcement of an emotional reaction, it is precisely the differences in regulation that lead to significant differences in consequences on the individual, e.g. health (Mauss, Bunge \& Gross, 2007). When suppression of emotions is chronic and non-discriminatory in relation to social demands, it can lead to reduced efficiency of cognitive processing (Dankić, 2004). This idea encouraged us to investigate the relation between personality traits and emotional styles, i.e. to investigate whether affective styles of behaviour can be predicted by specific personality traits.

Personality traits. Big Five model presupposes the existence of five basic dimensions of personality which were discovered during the analysis of natural languages, as well as during the analysis of psychological measuring instruments: neuroticism, extraversion, openness, agreeableness, conscientiousness (Pervin, Cervone \& 
John, 2008). The major foundation of this model was the logical assumption and lexical hypothesis that personality traits important to people, which are used for mutual comparison, are encoded in the language people use and that there are certain words for those traits that are used in everyday conversation. The basic function and significance of Big five model is reflected in its integrativity (integrity) and ability to present different systems in a unique frame, i.e. it made it easier to research and perceive personality dimensions (Pervin, Cervone \& John, 2008).

Neuroticism (Smederevac \& Mitrović, 2018) includes indicators of anxiety, tension, and bad mood. Neuroticism refers to the tendency to experience negative emotions. It refers to emotionally reactive people, who often feel anxiety, fear, or depression. Individuals who score high on neuroticism respond emotionally to the stimuli that other people remain indifferent to or unbothered. These people tend to interpret harmless events as threats and inconsiderable frustrations as insurmountable difficulties. It is precisely the problems in emotion regulation that can lead to faulty reasoning and assessment of reality, which reduces their effectiveness in dealing with stressful situations. According to some authors, (Ross, Canada \& Rausch, 2002), emotionally unstable people are prone to 'self-handicapping', i.e. they underestimate themselves and thus create obstacles to successful achievement in competitive situations or situations of measuring achievements, or with the purpose of protection of someone's self-esteem (Larsen \& Buss, 2008). On the other hand, people who score low on neuroticism are not disturbed easily and they regulate their emotionality more adaptively. These people are prone to be cold-blooded, serene, and calm. However, what is important is that low scores on this dimension do not mean the tendency to experience positive emotions. Positive emotionality is covered by the extraversion dimension (Smederevac \& Mitrović, 2018).

Extraversion (Smederevac \& Mitrović, 2018) encompasses traits such as being talkative, assertive, and energetic. Extraversion is characterized by a striking orientation towards the external environment. It means being surrounded by other people, having a lot of energy and being dominantly in a good mood. Individuals who score high on this dimension have a lot of enthusiasm, they like action, they attract attention, and they are talkative. Extraverts are usually happier and they experience more positive emotions with higher intensity (Fleeson, Malanos \& Achille, 2002). On the other 
hand, individuals who score low on this dimension are introverts who do not lead an active, socially rich and energetic life. They manifest the tendency to be quiet, closed, thoughtful, and distanced from the social world. These people do not prefer high level of stimulation and their lack of social engagement must not be identified with shyness or depression.

Openness to experience includes traits such as imaginativeness and a wide range of interests. It is a dimension of cognitive style, which distinguishes imaginative, creative people from mundane and conventional ones. Open people are intellectually curious, sensitive to beauty and art. They also have a clearer awareness of their own feelings. They show a tendency toward individualism and non-conformism (Smederevac \& Mitrović, 2018). Individuals who score low on this dimension have narrow, common interests. They can express suspicion and scepticism towards scientific and artistic achievements. These people are unwilling to change and generally prefer familiar things. One of possible reasons for openness can be found in individual differences in information processing. Contemporary research show that people who score high on the openness scale have more difficulties in ignoring previously experienced stimuli (Peterson, Smith \& Carson, 2002). It is like the 'doors' for perception and information processing are wide 'open' for the reception of information gathered from different sources over time. Less-open people have narrower consciousness and they ignore the stimuli more easily (Larsen \& Buss, 2008).

Agreeableness is a dimension which includes traits such as compassion, kindness, and loyalty. It denotes individual differences in cooperativeness with other people. Agreeable people like to be in the company of others. They are attentive, kind, generous, and prone to compromises in order to maintain harmonious relationships. Agreeable people basically have an optimistic view of human nature. They consider people to be basically honest and that they can be trusted (Smederevac \& Mitrović, 2018). People who score high on this dimension prefer the use of negotiations when handling conflicts, while people who score low on this dimension try to use their social power in solving conflicts (Graziano \& Tobin, 2002).

Individuals who score low on this dimension put their own interests above the interests of others. They are essentially indifferent to the well-being of others. They can also show suspicion about the motives of others, which makes them non-cooperative and often hostile to other people. This feature is very important for gaining 
and maintaining popularity, as people prefer agreeable persons. However, agreeableness as a feature is undesirable in situations requiring firmness or making decisions completely objectively.

Conscientiousness includes features such as propensity for planning, organization, and efficiency (Larsen \& Buss, 2008). It refers to the way in which a person controls, regulates and directs their impulses. Conscientious people avoid trouble and are successful in planning and targeting activities. Others often regard them as reliable and capable (Smederevac \& Mitrović, 2018). When individuals have extremely high scores on this dimension, they can be obsessively pedantic or workaholics and others can consider them boring. On the other hand, people who achieve low scores are unreliable and display a lack of ambition and inability to direct themselves to a particular activity. Such persons do not stay in one place for a long time and others will certainly not consider them boring.

Emotion control. The research of emotions has attracted the attention of scholars since ancient times, because their role in the daily functioning of people is indisputable. Modern emotion theories predominantly place emphasis on the positive and constructive aspects of emotions; however, emotions can be maladaptive, if they are of inappropriate intensity and/or are inadequate in a particular situation (Gross, 2008). Whether the emotions are adaptive or maladaptive depends also on whether the person views them as appropriate or exaggerated, acceptable or unbearable, understandable or meaningless, and the like (Žuljević, Radović \& Gavrilov-Jerković, 2010). In the last decades, there has been an increase in the interest of theoreticians and researchers in the field of emotions and strategies for their regulation (Amstadter, 2007).

It was noticed that children at the earliest age can (to some extent) manage their emotional experiences through emotional self-regulation. The goal of emotional self-regulation is to bring the intensity of the experienced emotions to a pleasant level. Even in the period when they are most helpless, in the first months of life, a self-regulation strategy has been recognized in turning from unpleasant anxieties. Therefore, children who are more successful in disregarding unpleasant stimuli show less inclination to anxiety (Axia, Bonichini \& Benini, 1999, according to Berk, 2005). As children grow up, they adopt different strategies in self-regulation. By using the language, talking to themselves, children can reduce the intensity of stimuli induced by emotions. Children whose parents 
have difficulty in controlling anger and hostility show difficulties in emotional self-regulation, which further adversely affects the psychological adaptation of the child (Eusenberg et al., 1999, according to Berk, 2005). At the age of ten and younger, children associate the implementation of a specific strategy for the regulation of emotions with the information whether or not they can control the situation; when they can somewhat control the situation they apply strategies to solve problems or seek social support. If they cannot control the situation, they apply a strategy of distraction or redefinition of the situation. At a time when emotional self-regulation develops sufficiently, children of school age gain a sense of emotional self-efficacy, i.e. of controlling their own emotional experiences. Such children show a higher degree of empathy and pro-social behaviour, as opposed to children who are overwhelmed with unpleasant emotions, which negatively reflects on pro-social behaviour, due to poor emotional self-regulation (Berk, 2005). As adults are often expected to inhibit emotional reactions, whether pleasant or unpleasant, it follows that it is not in all cases a pathogen. When a person suppresses negative emotions, it is difficult for collocutors to make their accurate decoding (Gross et al., 1998, according to Aronson, Wilson \& Akert, 2002), which leads to further communicational interaction in a non-constructive direction. Inhibition in some situations can also be adaptive. Recent research shows that people prone to suppression declare that they have a lower level of distress than those using confrontational strategies (Dankić, 2004). As the function of emotions is adaptive, Milivojević (2014) indicates-by intersecting the dimensions of emotional reaction and emotional control-that the individuals who are able to choose when it is appropriate to have a certain feeling, and when not, and accordingly, repress, the emotion or not, have the greatest flexibility and adaptability.

Emotion regulation is defined as a set of all processes related to the monitoring, evaluating, and modifying emotional reactions. Thus, emotional regulation refers to the process in which people monitor and evaluate emotions they feel, when they occur and how they manifest themselves (Gross, 2008). Gratz and Roemer (2004) state that emotion regulation includes the understanding, awareness, and acceptance of one's emotions, the ability to control impulsive behaviours and to act in accordance with the desired goals when experiencing feelings, as well as the ability to flexibly use situational strategies of emotion regulation to modulate an 
emotional response in order to attain personal goals and meet situational demands. According to these authors, difficulties in emotional regulation, or emotion dysregulation, arise from the relative absence of some or all of these abilities (Gratz \& Roemer, 2004).

The strategy of emotion regulation based on the Gross process model of emotion regulation, is often found in literature (Gross, 2008). According to this model, the emergence of emotions is a process that begins by the evaluation of emotional signs-a person assesses the situation, that is, the aspects of the situation that matter to their personal domain. Depending on the way in which the emotional sign is evaluated, the corresponding related set of responsive tendencies, consisting of human experiential, behavioural and physiological systems, is included. Gross (2008) presumes the existence of five types of specific strategies in the process of developing emotion regulation, which can be located and differentiated in the process of developing an emotional response: 1 ) selection of the situation; 2) modification of the situation; 3) deployment of attention; 4) change of cognitions that can lead to re-evaluation; 5) modulation of responses, which can lead to the suppression of emotional response (Gross, 2008). There are individual differences in personality traits when selecting situations. For example, extravert will choose social situations because this causes a positive affect in him, an aggressive person will choose situations in which they can confront other people, while depressed people will not differ from those who are not depressed in the amount of objective stress and misery, but will differ in the frequency of events that may cause a depressive reaction (Gross, 1999). Regarding the modification of the situation, the assertive and dominant person will try to affect the change of the situation, unlike the submissive and non-assertive people who will rather tolerate the unfavourable situation. Within the dimensions of the personality defined by the Big Five model, two dimensions are particularly emotionally colored: neuroticism, which is saturated with negative emotionality, and extraversion which is saturated with positive emotionality (Popov, 2010). A higher degree of neuroticism also implies greater reactivity to different stimuli that need not be strong to cause anxiety. On the other hand, the active and exciting life of the extraverts can be a reflection of the tendency towards the experience of positive emotions (Smederevac \& Mitrović, 2018). According to some studies (Gutiérrez, Jiménez, Hernández \& Puente, 2005) there is a positive correlation between openness to experience as a personality dimension 
and positive and negative affects. The results of the study also show that agreeableness is related to pro-social behaviour and a positive affect (Mauss, Cook \& Gross, 2007).

With all this in mind, Hoffman and Kashdan (2010) concluded that different strategies of emotion regulation can be conceptually reduced to three basic styles of affective regulation - suppression, concealing, and tolerating of emotions. On the Serbian population, Žuljević, Radović \& Gavrilov-Jerković (2010) conducted a test of the psychometric characteristics and validation of Affective Style Questionnaire (ASQ) by Hoffman and Kashdan and confirmed the applicability of the instrument, but also suggested further research.

Literature review has not shown any research on relationships between personality traits and affective styles, as defined by Hoffman and Kashdan, and we considered it important to examine whether emotion regulation strategies can be predicted based on personality traits.

\section{METHODOLOGY}

RESEARCH The research problem was to examine whether certain affective SUBJECT styles can be predicted on the basis of personality traits, that is, to what extent personality traits are significant predictors of affective styles. Accordingly, the specific objectives of the research were to determine the degree of expression of personality traits and affective styles, to determine whether there is a correlation between certain personality traits on the one hand and individual affective styles on the other, as well as whether there are gender differences in the expression of these variables.

INSTRU- The following instruments have been used in the research:

MENTS

Big Five Inventory - BFI (Benet-Martinez \& John, 1998, according to Knežević, Džamonja-Ignjatović \& Đurić-Jočić, 2004) originated as the operationalization of Big Five model and consists of 44 items formulated in the form of short phrases based on adjectives of personality traits that are the prototype of the five-factor model. The task of the respondents is to estimate on the Likert-type scale from 1 (I completely disagree) to 5 (I completely agree) to what extent the individual assertion refers to them. The inventory has five subscales: Neuroticism (8 items), Extraversion (8 items), Openness to 
experience (10 items), Agreeableness (9 items) and Conscientiousness (9 items). The reliability of the subscales expressed through the Cronbach alpha coefficient is on the sample from this research: Neuroticism $\alpha=.73$, Extraversion $\alpha=.71$, Openness $\alpha=.69$, Conscientiousness $\alpha=.75$, Agreeableness $\alpha=.72$.

Affective Style Questionnaire - ASQ (Hofmann \& Kashdan, 2010) consists of 20 items. It includes three subscales which represent self-description three-style measures, that is, the affect-regulation strategies: Concealing (8 items), Adjusting ( 7 items), and Tolerating (5 items). The respondent answers the five-level Likert-type scale, indicating the degree of agreement with the stated claim. The questionnaire allows three scores indicating the preference of individual strategies. The Concealing subscale aims to indicate the tendency of the respondents to conceal or suppress the emotional state that they are experiencing at a given moment. The Adjusting subscale indicates the respondent's inclination to successfully adapt to the demands of the situation in which the emotion occurs while the Tolerance subscale indicates the respondent's inclination to accept and tolerate one's own emotions, including unwanted and aversive reactions. Hoffman and Kashdan (2010) expect that the person's tendency to adapt to the demands of the situation and to tolerate their own emotions, and to conceal them and suppress them to the least extent possible, are a reflection of a functional affective style that should contribute to the increase in the psychological well-being of a person, thus preventing the appearance of the sign of more permanent psychological distress, which has been confirmed by the research (Tuneberger, 2011). Reliability of the subscales expressed by Cronbach alpha coefficient on the examined sample is: Concealment $\alpha=82$, Adjusting $\alpha=.79$, Tolerating $\alpha=.75$.

Demographic survey questions are about respondents' gender, age, faculty, and the year of study.

SAMPLE AND The sample consists of 171 students from the University of Priština PROCEDURE in Kosovska Mitrovica. The gender structure is such that there are more female students (67.3\%) than male (32.2\%). Most respondents are from the Faculty of Philosophy (47.4\%), from the Faculty of Law (32.7\%), and the Faculty of Economics (19.9\%). All respondents are students of bachelor studies, first year students make $55.6 \%$, and second year students $44.4 \%$ of the respondents. The age of the respondents ranged from 18 to 26 years of age $(M=19.65 ; \mathrm{SD}=1.16$; $\mathrm{Mdn}=19)$. The research was conducted at the faculty premises. The 
test was anonymous and the respondents voluntarily participated in the research, after the goal was explained and it was indicated that the data would be used for research purposes only. Statistical methods used include descriptive statistics, correlation, regression analysis, and t test.

\section{STUDY RESULTS}

Table 1 shows the descriptive indicators of personality traits and affective styles. As the dimensions of the personality contain a different number of items, in order to compare the expression of individual dimensions of the personality, the correction of the scores has been done by dividing the average value by the number of items on the subscale. The same procedure has been conducted for the scale of affective styles.

\begin{tabular}{|c|c|c|c|c|c|}
\hline & MIN. & MAX. & AS & SD & $\begin{array}{c}\text { CORRECTED } \\
\text { SCORES }\end{array}$ \\
\hline NEUROTICISM & 8 & 36 & 23,16 & 5,14 & 2,89 \\
\hline EXTRAVERSION & 15 & 40 & 28,65 & 4,51 & 3,58 \\
\hline OPENNESS & 23 & 46 & 34,57 & 4,42 & 3,46 \\
\hline CONSCIENTIOUSNESS & 19 & 45 & 32,19 & 5,46 & 3,58 \\
\hline AGREEABLENESS & 18 & 45 & 34,69 & 4,81 & 3,85 \\
\hline CONCEALING & 8 & 40 & 26,29 & 6,45 & 3,29 \\
\hline ADJUSTING & 8 & 35 & 24,36 & 5,41 & 3,48 \\
\hline TOLERATING & 8 & 43 & 16,57 & 3,92 & 3,31 \\
\hline \hline
\end{tabular}

TABLE 1: DESCRIPTIVE INDICATORS OF PERSONALITY TRAITS AND AFFECTIVE STYLES

The results of descriptive statistics show that the most pronounced dimension is the agreeableness, then the extraversion and conscientiousness, then the openness, while the least prominent dimension is the neuroticism. Regarding affective styles, the most pronounced is adjusting, then tolerating, and finally concealing.

Table 2 shows the results of the correlation analysis of personality traits and affective styles. Neuroticism has a statistically significant negative correlation with all three affective styles (concealing, 
adjusting, and tolerating), while extraversion has a statistically significant positive correlation with adjusting, and conscientiousness has a statistically significant positive correlation with adjusting and tolerating. The greatest correlation exists between neuroticism and adjusting. Openness and agreeableness do not have a statistically significant correlation with any aspect of the affective style.

\begin{tabular}{|c|c|c|c|}
\hline & CONCEALING & ADJUSTING & TOLERATING \\
\hline NEUROTICISM & $-.175^{*}$ & $-.590^{* *}$ & $-.267^{* *}$ \\
\hline EXTRAVERSION & -.104 & $.243^{* *}$ & .140 \\
\hline OPENNESS & .058 & .100 & .045 \\
\hline CONSCIENTIOUSNESS & -.117 & $.158^{*}$ & $.177^{*}$ \\
\hline AGREEABLENESS & -.104 & .035 & -.026 \\
\hline \hline
\end{tabular}

TABLE 2: CORRELATION BETWEEN PERSONALITY TRAITS AND AFFECTIVE STYLES

* Significance level $p<0.05$

** $\quad$ Significance level $p<0.01$

Further in the paper, we included personality traits (neuroticism, extraversion, openness, conscientiousness, and agreeableness) in the model of regression analysis, and scores on measured aspects of affective styles (concealing, adjusting, tolerating) as criterion variables.

Thus, Table 3 shows the multiple regression analysis where the predictor variables are personality traits (neuroticism, extraversion, openness, conscientiousness, and agreeableness) and the criterion variable is concealing. Personality traits account for $10.7 \%$ of the variance in concealing, and neuroticism $(\beta=-298 ; p<0.01)$ and extraversion $(\beta=-221, p<0.05)$ stands out in the group of predictor variables.

\begin{tabular}{||c|c|c|c|c|c|}
\hline $\begin{array}{c}\text { PERSONALITY } \\
\text { TRAITS }\end{array}$ & $\mathrm{R}$ & $\mathrm{R}^{2}$ & $\mathrm{~F}$ & $\beta$ & SIG. \\
\hline & .107 & .077 & 3,569 & & \\
\hline Neuroticism & & & & -.298 & $.001^{*}$ \\
\hline Extraversion & & & & -.221 & $.016^{* *}$ \\
\hline \hline
\end{tabular}

TABLE 3: PERSONALITY TRAITS AS PREDICTORS OF AFFECTIVE STYLE - CONCEALING 
Collection of Papers of the Faculty of Philosophy XLIX (3)/2019

\begin{tabular}{|l|l|l|l|c|c|}
\hline Openness & & & & .145 & .081 \\
\hline $\begin{array}{l}\text { Conscientious- } \\
\text { ness }\end{array}$ & & & & -.120 & .155 \\
\hline Agreeableness & & & & -.088 & .285 \\
\hline \hline
\end{tabular}

TABLE 3: PERSONALITY TRAITS AS PREDICTORS OF AFFECTIVE STYLE - CONCEALING

* $\quad p<0.01$

Personality traits account for $36.1 \%$ of the variance in adjusting, and neuroticism stands out with the negative pre-sign of $\beta$ coefficient $(\beta=-.596, p<0.01)$ as a significant predictor variable.

\begin{tabular}{|c|c|c|c|c|c|}
\hline PERSONALITY TRAITS & $\mathrm{R}$ & $\mathrm{R}^{2}$ & $\mathrm{~F}$ & $\beta$ & SIG. \\
\hline & .361 & .340 & 16,949 & & \\
\hline NEUROTICISM & & & & -.596 & $.000^{*}$ \\
\hline EXTRAVERSION & & & & -.012 & .874 \\
\hline OPENNESS & & & & .093 & .185 \\
\hline CONSCIENTIOUSNESS & & & & .035 & .621 \\
\hline AGREEABLENESS & & & & -.076 & .277 \\
\hline
\end{tabular}

TABLE 4: PERSONALITY TRAITS AS PREDICTORS OF AFFECTIVE STYLE - ADJUSTING $\mathrm{p}<0.01$

Also, personality traits account for $9.8 \%$ of the variance of tolerating, with neuroticism being the only significant predicting variable with a negative sign of the $\beta$ coefficient $(\beta=-.241, p<0.05)$.

\begin{tabular}{||c|c|c|c|c|c|}
\hline PERSONALITY TRAITS & $\mathrm{R}$ & $\mathrm{R}^{2}$ & $\mathrm{~F}$ & $\beta$ & SIG. \\
\hline NEUROTICISM & .098 & .068 & 3,234 & & \\
\hline EXTRAVERSION & & & & -.241 & $.006^{*}$ \\
\hline OPENNESS & & & & .022 & .809 \\
\hline $\begin{array}{c}\text { CONSCIENTIOUSNES } \\
\mathrm{S}\end{array}$ & & & & .027 & .744 \\
\hline AGREEABLENESS & & & & .148 & .081 \\
\hline \hline
\end{tabular}

TABLE 5: PERSONALITY TRAITS AS PREDICTORS OF AFFECTIVE STYLE - TOLERATING * $\mathrm{p}<0.01$ 
The use of $t$-test showed that there were gender differences in the expression of some personality traits (extraversion and agreeableness), while there were no gender differences in the expression of affective styles.

\begin{tabular}{|c|c|c|c|c|c|c|c|}
\hline & GENDER & $\mathrm{N}$ & AS & SD & $\mathrm{F}$ & $\mathrm{T}$ & SIG. \\
\hline \multirow{2}{*}{ NEUROTICISM } & MALE & 56 & 22,39 & 5,12 & \multirow{2}{*}{,104 } & \multirow{2}{*}{$-1,304$} & \multirow{2}{*}{.194} \\
\hline & FEMALE & 115 & 23,51 & 5,14 & & & \\
\hline \multirow{2}{*}{ EXTRAVERSION } & MALE & 56 & 27,49 & 4,39 & \multirow{2}{*}{, $295^{*}$} & \multirow{2}{*}{$-2,298$} & \multirow{2}{*}{.023} \\
\hline & FEMALE & 115 & 29,19 & 4,48 & & & \\
\hline \multirow{2}{*}{ OPENNESS } & MALE & 56 & 33,75 & 4,40 & \multirow{2}{*}{, 001} & \multirow{2}{*}{$-1,634$} & \multirow{2}{*}{.104} \\
\hline & FEMALE & 115 & 34,96 & 4,39 & & & \\
\hline \multirow{2}{*}{$\begin{array}{c}\text { CONSCIENTIOUSNE } \\
\text { SS }\end{array}$} & MALE & 56 & 31,28 & 5,11 & \multirow{2}{*}{,129 } & \multirow{2}{*}{$-1,480$} & \multirow{2}{*}{.141} \\
\hline & FEMALE & 115 & 32,62 & 5,59 & & & \\
\hline \multirow{2}{*}{ AGREEABLENESS } & MALE & 56 & 33,11 & 5,07 & \multirow{2}{*}{, $684^{* *}$} & \multirow{2}{*}{$-2,982$} & \multirow{2}{*}{.003} \\
\hline & FEMALE & 115 & 35,45 & 4,51 & & & \\
\hline \multirow{2}{*}{ CONCEALING } & MALE & 56 & 27,19 & 5,49 & \multirow{2}{*}{2,091} & \multirow{2}{*}{1,205} & \multirow{2}{*}{.230} \\
\hline & FEMALE & 115 & 25,88 & 6,83 & & & \\
\hline \multirow{2}{*}{ ADJUSTING } & MALE & 56 & 24,82 & 5,34 & \multirow{2}{*}{, 047} & \multirow{2}{*}{,744 } & \multirow{2}{*}{.458} \\
\hline & FEMALE & 115 & 24,14 & 5,45 & & & \\
\hline \multirow{2}{*}{ TOLERATING } & MALE & 56 & 16,25 & 3,01 & \multirow{2}{*}{2,543} & \multirow{2}{*}{,- 702} & \multirow{2}{*}{.484} \\
\hline & FEMALE & 115 & 16,72 & 4,27 & & & \\
\hline
\end{tabular}

TABLE 6: GENDER DIFFERENCES IN THE EXPRESSION OF PERSONALITY TRAITS AND AFFECTIVE STYLES

* Significance level $p<0.05$

** Significance level $p<0.01$

Female respondents scored higher on the dimensions of extraversion and agreeableness compared to male respondents.

\section{DISCUSSION AND CONCLUSION}

The starting assumption of the paper was that personality traits are significant in predicting affective styles among young people.

The results of descriptive statistics showed that the most pronounced trait was the agreeableness, while the most pronounced affective style was the adjusting. The respondents are characterized 
by their kindness and cooperativeness with other people. They are optimistic, loyal, and strive to maintain harmonious relationships. Respondents were also shown to have the ability to successfully adapt to the demands of the situation in which the emotion occurred.

The results of the correlation analysis showed that neuroticism is negatively associated with all three affective styles (concealing, adjusting, and tolerating), whereas extraversion is positively associated with adjusting, and conscientiousness with adjusting and tolerance. When individuals exhibit low neuroticism, that is, when they are emotionally stable, then they will be able to regulate their emotionality more adequately, i.e. they will be able to inhibit their emotions, adjust, or accept them in certain situations. Extraverts, due to their outward orientation and dominant positive mood, have the ability to adapt to the external environment in which emotions occur. Conscientious persons have the ability to plan, organize, control, regulate, and direct their impulses and thus are able to accept their own emotions.

Furthermore, the results of the regression analysis showed that personality traits account for 10 to $36 \%$ of the variance in affective styles and that neuroticism and extraversion stand out as significant predictors. Neuroticism gives a significant contribution to predicting adjusting and tolerating, with a negative sign of the $\beta$ coefficient, while extraversion gives a significant contribution to predicting the concealing, also with a negative sign of the $\beta$ coefficient. The results thus obtained can be explained by the very characteristics of personality dimensions. Namely, if we bear in mind that $\beta$ is a coefficient with a negative sign, then we are talking about persons with low neuroticism, i.e. emotionally stable individuals who will be able to adapt or accept their own emotions. These individuals are characterized by the capacity to cope with stressful situations on their own, they are characterized by cold-bloodedness and stability, even in situations that other people find disturbing (Smederevac \& Mitrović, 2018). With this in mind, it was expected that such individuals would also have the capacity to tolerate emotions and adjust them, which would enable them to respond adaptively to the daily reward and punishment signals, thereby reducing the likelihood of anxiety and depression (Hoffman \& Kashdan, 2010). Also, if we bear in mind the characteristics of extraverts such as the ability to experience and recognize positive emotions, it was expected that such persons would not be 
prone to concealing or suppressing the emotional state they were experiencing at a given moment. It is the state of satisfaction that is achieved through increased activity, optimism, and active search for situations that will lead to positive outcomes (Smederevac \& Mitrović, 2018). The results obtained by Popov (2010) on a sample of the general population, aged 17-68, support the results that personality traits neuroticism and extraversion are especially emotionally coloured, and that neuroticism is otherwise called "negative emotionality" and extraversion "positive emotionality". A great deal of research has shown that affective styles depend on personality traits (Costa, McCrae \& Zonderman, 1987; Diener \& Diener, 1996, according to Mroczek \& Kolarz, 1998) if emotionality at the level of positive and negative affect is generalized as a level of happiness and well-being. Thus, earlier longitudinal studies have confirmed the stability of positive and negative affectivity over time, as well as the dimensions of personalities associated with them, which supports the thesis of heritability of these constructs (Costa, McCrae \& Zonderman, 1987, according to Mroczek \& Kolarz, 1998; Watson \& Clark, 1994).

When it comes to gender differences in the expression of personality traits, female respondents scored higher in the dimensions of extraversion and agreeableness, which has also been obtained in other studies (Costa \& McCrae, 1980). Regarding affective styles, no gender differences were obtained. There are no data on gender differences in the expression of affective styles in the works of other researchers (Hofmann \& Kashdan, 2010; Žuljević, Radović, \& Gavrilov-Jerković, 2010).

The significance of this research is reflected in the understanding of the relationship between personality traits and affective styles. However, some limitations of the research should be kept in mind regarding the sample and the instruments used. The sample was suitable and consisted of students, so the obtained results cannot be generalized to another population. Moreover, the gender structure was such that there were more female respondents (67.3\%) than male respondents $(32.2 \%)$. The restriction on the instruments used relates to the lower reliability of Big Five Inventory (BFI), where individual subscales of this inventory had a reliability expressed by an alpha coefficient below 0.70 , which represents an arbitrary limit that the instrument can be considered reliable.

As the research is about a student population, which in this life period is facing different developmental tasks as the sources of 
emotions, but also the place of study as a source of emotions, suggestions for future research can direct to comparing our results with those of the student population outside the territory of Kosovo and Metohija, but also with the results of the adult population. Furthermore, it is possible to make insight into personality traits predicting the affective styles by applying the Five-Factor Model, and thus check whether the relations obtained by this research are constant with respect to the content of dimensions of these two personality models. Both observed constructs of the research, personality traits and emotion regulation, develop in stronger or weaker social context. Suggestions for future research may also seek for an answer as to whether the specifics of the social milieu (e.g. certain interaction processes, upbringing style, upbringing goals, etc.) that dominantly develop a particular dimension of personality also develop a particular affective style.

REFERENCES Amstadter, A. (2007). Emotion regulation and anxiety disorders. Journal of Anxiety Disorders, 22, 211-221.

Aronson, E., Wilson, T. D., Akert, R. M. (2002). Social Psychology. New York: Prentice Hall.

Berk, L. (2005). Psihologija cjeloživotnog razvoja. Jastrebarsko: Naklada Slap.

Costa, P. T. \& McCrae, R. R. (1980). Still stable after all these years: Personality as a key to some issues in adulthood and old age. In: P. B. Baltes \& G. Brim (Eds.). Lifespan development and behavior 3 (65-102). New York: Academic Press.

Dankić, K. (2004). Emocionalna kontrola i zdravlje. Psihologijske teme, 13, 19-32. Fleeson, W., Malanos, A. B, \& Achille, N. M. (2002). An Intraindividual Process Approach to the Relationship Between Extraversion and Positive Affect: Is Acting Extraverted as "Good" as Being Extraverted? Journal of Personality and Social Psychology, 83 (6), 1409-1422.

Graziano, W. G., \& Tobin, R. M. (2002). Agreeableness: dimension of personality or social desirability artifact? Journal of personality, 70 (5), 695-727.

Gratz, K. \& Roemer, L. (2004). Multidimensional Assessment of Emotion Regulation and Dysregulation: Development, Factor Structure and Initial Validation of the Difficulties in Emotion Regulation Scale. Journal of Psychopathology and Behavioral Assessment, 26 (1), 41-54.

Gross, J. J. (2008). Emotion Regulation. In: M. Lewis, J. M. Haviland-Jones, L. F. Barrett (Eds.), Handbook of Emotions (497-512). New York: The Guilford Press.

Gross, J. J. (1999). Emotion and emotion regulation. In: L.A. Pervin, O.P. John (Eds.). Handbook of personality: Theory and research (525-552). New York: The Guilford Press. 
Gross, J. J. \& Levenson, R. W. (1997). Hiding Feelings: The Acute Effects of Inhibiting Negative and Positive Emotion. Journal of Abnormal Psychology, 106, 95-103.

Gutiérrez z, J. L., Jiménez, B. M., Hernández, E. G., \& Puente, P.C. (2005). Personality and subjective well-being: Big five correlates and demographic variables. Personality and Individual Differences, 38, 1561-1569.

Hofmann, S. G. \& Kashdan, T. B. (2010). The Affective Style Questionnaire: Development and Psychometric Properties. Journal of Psychopathology and Behavi oral Assessment, 32, 255-263.

Knežević, G., Džamonja-Ignjatović, T., \& Đurić-Jočić, D. (2004). Petofaktorski model ličnosti. Beograd: Centar za primenjenu psihologiju.

Larsen, R. J. \& Buss, D. M. (2008). Psihologija ličnosti. Područja znanja o ljudskoj prirodi. Jastrebarsko: Naklada Slap.

Mauss, I. B., Bunge, A. S., \& Gross, J. J. (2007). Automatic emotion regulation. Social and Personality Psychology Compass, 1, 146-167.

Mauss, I. B., Cook, C. L., \& Gross, J.J. (2007). Automatic emotion regulation during anger provocation. Journal of Experimental Social Psychology, 43, 698-711.

Milivojević, Z. (20014). Emocije: psihoterapija i razumevanje emocija. Novi Sad: Psihopolis Institut.

Mroczek, K. D. \& Kolarz, C. M. (1998). The effect of age on positive and negative affect: A developmental perspective on happiness. Journal of Personality and Social Psychology, 75, 1333-1349.

Pervin, L. A., Cervone, D., \& John, O. P. (2008). Psihologija ličnosti: teorije $i$ istraživanja. Zagreb: Školska knjiga.

Peterson, J. B., Smith, K. W., \& Carson, S. (2002). Openness and extraversion are associated with reduced latent inhibition: Replication and commentary. Personality and Individual Differences, 33 (7), 1137-1147.

Popov, S. (2010). Relacije kognitivne emocionalne regulacije, osobina ličnosti i aktiviteta. Primenjena psihologija, 1, 59-76.

Reeve, J. (2010). Razumijevanje motivacije i emocija. Jastrebarsko: Naklada Slap.

Ross, S. R., Canada, K. E., \& Rausch, M. K. (2002). Self-handicapping and the Five Factor Model of personality: Mediation between neuroticism and conscientiousness. Personality and Individual Differences, 32 (7), 1173-1184.

Smederevac, S. \& Mitrović, D. (2018). Ličnost - metode i modeli. Treće dopunjeno i izmenjeno izdanje. Beograd: Centar za primenjenu psihologiju društva psihologa Srbije.

Žuljević, D., Radović, D., \& Gavrilov-Jerković, V. (2010). Psihometrijska provera i validacija upitnika afektivnih stilova na srpskom uzorku. Primenjena psihologija, 6 (1), 45-65.

Watson, D., \& Clark, A., L. (1994). The PANAS-X manual for the positive and negative affect schedule-expanded form. The University of Iowa. 
ЈЕЛЕНА И. ДАВИДОВИЋ РАКИЋ

МИљАНА С. ПАВИЋЕВИЋ

УНИВЕРЗИТЕТ У ПРИШТИНИ СА ПРИВРЕМЕНИМ СЕДИШТЕМ

У КОСОВСКОЈ МИТРОВИЦИ, ФИЛОЗОФСКИ ФАКУЛТЕТ

КАТЕДРА ЗА ПСИХОЛОГИЈУ

РЕЗИМЕ

ОСОБИНЕ ЛИЧНОСТИ КАО ПРЕДИКТОРИ

АФЕКТИВНИХ СТИЛОВА КОД МЛАДИХ

Рад је усмерен на сагледавање предикције особина личности у предвиђању афективног стила младих. Узорак испитаника чини 171 студент Универзитета у Приштини, са привременим седиштем у Косовској Митровици, оба пола, узраста од 18 до 26 година. Прикупљени подаци обрађени су дескриптивном статистиком, корелационом и регресионом анализом, као и т-тестом. Најизраженија димензија личности је пријатност, а од афективних стилова прилагођавање. Потврђена је предикција димензија личности у предвиђању одређеног афективног стила, и то тако да је неуротицизам кључан у предикцији сва три афективна стила. У предикцији афективног стила прикривање особине личности као модел објашњавају 10,7\% варијансе, а допринос поред неуротицизма $(\beta=-298 ; \Pi<0,01)$ даје и екстраверзија $(\beta=-221$, $\Pi<0,05)$. Особине личности објашњавају $36,1 \%$ варијансе прилагођавања, а јединствени допринос даје неуротицизам $(\beta=-, 596$, $\Pi<0,01)$, док у предикцији афективног стила толерисање особине личности објашњавају 9,8\% укупне варијансе, а као значајан предиктор се издвојио неуротицизам $(\beta=-, 241, \Pi<0,05)$. Пол се није показао као значајан извор разлика у изражености афективних стилова, док постоје полне разлике у изражености екстраверзије и пријатности у корист испитаника женског пола.

КљУЧНЕ РЕЧИ: особине личности; афективни стил; млади.

Овај чланак је објављен и дистрибуира се под лиценцом Creative Commons Ауторство-Некомерцијално Међународна 4.0 (СC BY-NC 4.0 |

https://creativecommons.org/licenses/by-nc/4.0/).

This paper is published and distributed under the terms and conditions of the Creative Commons Attribution-NonCommercial International 4.0 licence (CC BY-NC 4.0 | https://creativecommons.org/licenses/by-nc/4.0/). 